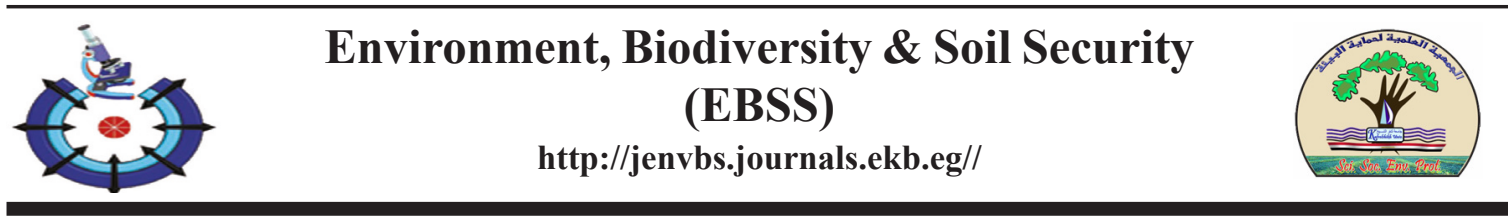

\title{
Maximizing Productivity of Peanut (Arachis hypogaea L.) Plants in Sandy Soils Using Environmental Safe Fertilizers
}

\author{
Ahmed M. Elbaalawy ${ }^{*}$, Manal F. Tantawy ${ }^{2}$ and Naglaa E. El-Noamany ${ }^{1}$ \\ ${ }^{1}$ Department of Soil Science, Faculty of Agriculture, Menoufia University, Egypt \\ ${ }^{2}$ Soils, Water and Environment Research Institute, Agriculture Research Center, Giza, \\ Egypt
}

\begin{abstract}
$\mathbf{R}^{\mathrm{t}}$ ECENT fertilization strategies in the world show that the use of environment safe fertilizers is of great importance to decrease the harmful effects of fertilizers on environment and human health, especially in the newly reclaimed soils. Therefore, this study was carried out to evaluate the effect of some environmental safe fertilizers (i.e., organic and bio fertilizers) in different sources on sandy soil productivity of peanut plants (Arachis hypogaea L.). The used organic fertilizers were farmyard manure (FYM), solid plant compost (SPC), enriched compost tea with humic substances (ECT) and mixture of FYM and ECT, while the used bio- fertilizers were B1 (Azospirillum braselinse + Bacillus megatherium + Azotobacter chroococcum) and B2 (Bradyrhizobium sp. USDA 3456+ Serratia marcescens MH6+ Psuedomonas fluorescens IFO 2034. The obtained data showed the superior increase effect of ECT followed by FYM+ECT applications straw, pods and seed yields straw and seeds contents of N, P and K as well as seeds contents of protein and oil. Similar increase for all determined parameters were found in the plants inoculated by B2 compared to that with B1. Thus, use of both organic and bio- fertilizers in the fertilization strategy of sandy soil is very important and also may be economically.
\end{abstract}

Keyword: Azospirillum braselinse, Organic fertilizers, Bio-fertilizers, Bacillus megatherium.

\section{Introduction}

Peanut (Arachis hypogaea L.) is one of the most valuable oil leguminous crops in Egypt. Its seeds are characterized by high content of oil (45 to $50 \%$ ), protein (22 to $28 \%$ ), carbohydrate $(20 \%)$ and 5\% fiber and ash (Fageria et al., 1997 and Zaki et al., 2017). Besides its high nutritional value for humans, peanut byproducts are also important for livestock feeding such as produced cake as well as the green leafy straw (Shah et al., 2012).

In Egypt, peanut is mainly grown in the northern part of the country in the newly reclaimed desert areas of East and West Nile Delta. These areas are mainly sandy soils, which have low organic matter content, poor physical conditions and low content of available and total essential nutrients (Ghabour et al., 2018). Due to low levels of available nutrients in sandy soils, high rates of NPK mineral fertilizers are used to maximize seed and straw yields, which used for human and animal feeding, respectively (El-Behlak, 2016). Mineral fertilizers application resulted in a significant increase in yield and yield components, while very high rates of their application can cause soil and water pollution and need to be reduces (Mengel et al., 2001). Organic manures and bio-fertilizers are alternatives to increase soil productivity of different crops without polluting the environment in a sustainable production system (Faiyad, 2014). Bio-fertilizers are eco-friendly and have several advantages over conventional chemicals. It is safer than many of the chemicals, not toxic substances, does not accumulate in the food chain

"Corresponding author; email: a baalawy@yahoo.com

Received 22/05/2020; Accepted 7/07/2020

DOI: $10.21608 /$ jenvbs.2020.30824.1098

(C)2020 National Information and Documentation Center (NIDOC) 
and not considered harmful to the environment or ecological processes. Self-replication of microbes circumvents the need for repeated application (Wua et al., 2004). Application of organic manures is widely recommended especially in sandy soils deficient in soil organic matter. Application of organic fertilizers to such soil types (sandy) found to improve physical, chemical and biological properties and increase nutrient availability (Helmi, 2018). Abou Hussien et al. (2019) reported that application of composted three organic materials improves soil chemical properties and its content of available nutrients as well as yield of wheat. Combined application of organic and bio-fertilizers is widely recommended to improve physical, chemical and biological properties of soil and to achieve high yields free from undesirable pollutants (Ansari and Mahmood, 2017 and Gao et al., 2020). Zaki et al. (2017) found that application of both bioand organic fertilizers to different peanut cultivars grown in sandy soil resulted in improved yield and yield components. Increasing the yield of peanut by applying integrated action of both mineral and bioorganic fertilizers was reported before that by Subrahmaniyan et al. (2000) and El-Howeity et al. (2019).

The present study aims at developing a suitable fertilization management system that integrates the use of environmental safe bio and organic fertilizers to maximize yield of peanut plants cultivated in a sandy soil.

\section{Materials and Methods}

A field experiment was carried out on a sandy soil of Experimental Farm, Ismailia Research Station, Soils, Water and Environment Research Institute, Agricultural Research Center (ARC), Egypt, during two successive growth summer seasons (i.e., 2016 and 2017) to study the effect of environmentally friendly fertilizers (bio and organic) on peanut (Arachis hypogaea L.) Giza 5 cv. yield quantity and quality as well as N, P and $\mathrm{K}$ uptake.

Before planting, soil samples at soil depth of $0-20 \mathrm{~cm}$ were taken from the experimental soil, air-dried, ground, mixed thoroughly, sieved through a $2 \mathrm{~mm}$ sieve, kept and analyzed for some physical and chemical properties and its content (total and available) of N, P and $\mathrm{K}$ according to the methods described by Cottenie et al. (1982); Page et al. (1982) and Klute (1986). The obtained data are recorded in Table 1.

In this study, four sources of organic fertilizer were used. These fertilizers were:

1- Farmyard manure "FYM" which was taken from private farm of animal husbandry.

2- Solid plant compost "SPC" which was prepared at Agricultural Microbiology Research Department, Soils, Water and Environment Research Institute, Agricultural Research Center (ARC), Egypt, from rice straw and farmyard manure provided with bentonite, rock phosphate, elemental sulphur and urea, which were composted for three months.

TABLE 1. Some physical and chemical properties of the studied soil and its content of some nutrients

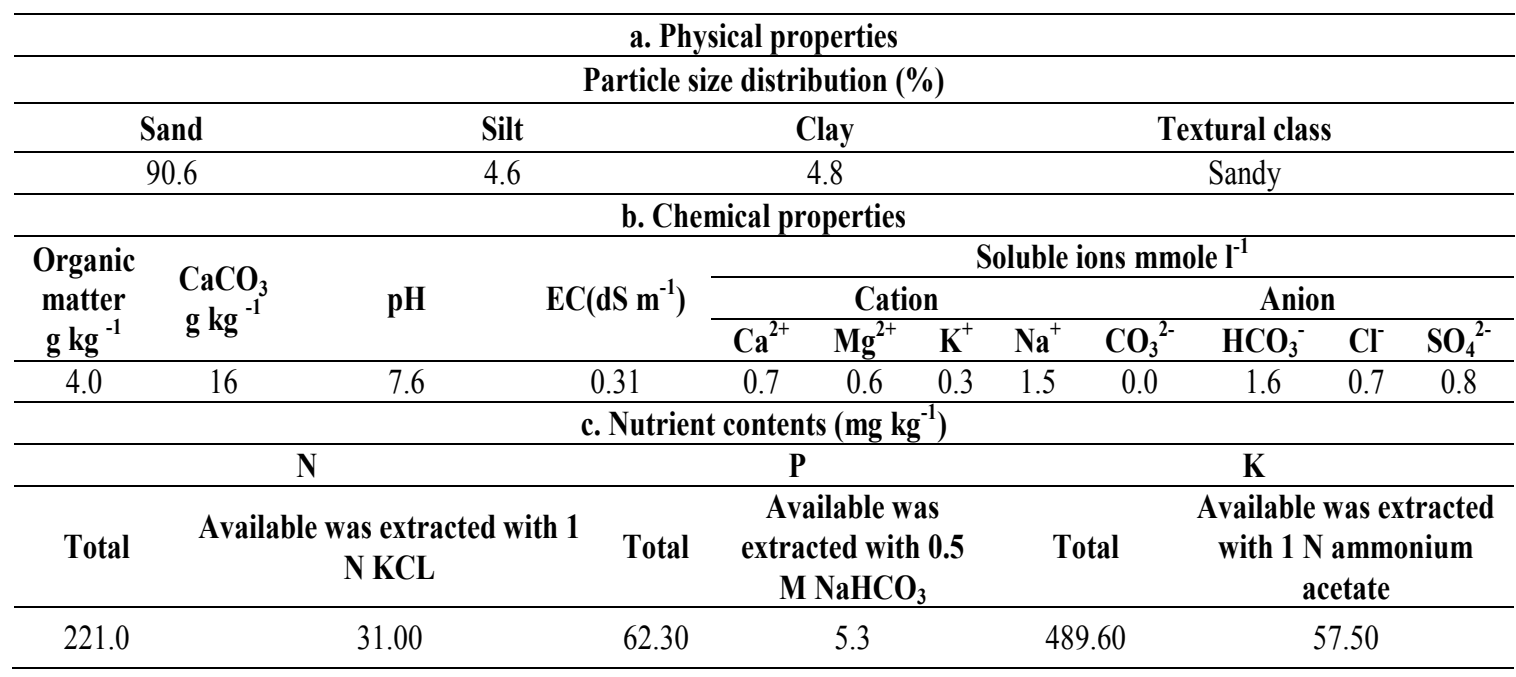

Soluble ions mmole 1-1 in 1:5 soil water extract; EC (dS m-1) in saturated soil past; PH (1:2.5) in soil: water suspension 
3- Enriched compost tea "ECT", prepared from a well mature compost enriched with humic substances.

4- A mixture of farmyard manure and enriched compost tea "FYM" + "ECT".

Samples of FYM, SPC and ECT were taken and analyzed for their chemical composition according to the methods described by Cottenie et al. (1982) and Page et al. (1982). The obtained data are recorded in Table 2.

\section{Enriched compost tea (ECT)}

Aerated compost tea was prepared from a matured compost made from rice straw according to the method described by Abdel-Wahab et al. (2007) as follows: $10 \mathrm{~kg}$ of mature compost was blended with $1 \mathrm{~kg}$ molasses, $500 \mathrm{~g}\left(\mathrm{NH}_{4}\right)_{2} \mathrm{SO}_{4}$, $50 \mathrm{~g} \mathrm{MgSO}_{4} .7 \mathrm{H}_{2} \mathrm{O}$ and $10 \mathrm{~g} \mathrm{NaCl}$ were put in a 150 liter plastic barrel and drenched in 100 litter tap water previously stored to avoid the harmful effect of $\mathrm{Cl}$ on microbial load of compost. Then the mixture was supplied with $2.5 \mathrm{~mL} / \mathrm{L}$ of humic substances (prepared from steeping $10 \mathrm{~kg}$ solid compost in 100 litter of $0.5 \mathrm{~N} \mathrm{KOH}$ solution).

\section{Biofertilizers}

Bio-fertilizers were performed by using two (B1 and B2) different mixtures (blends) of bacterial agents at a single dose, and supplied by Agricultural Microbiology Research Department, Soils, Water and Environment Research Institute, Agricultural Research Center (ARC), Egypt. All bacterial agents used as plant growth promoting rhizobacteria (PGPR) and represented by the following mixtures:
- B1 consist of Azospirillum braselinse+ Bacillus megatherium + Azotobacter chroococcum.

- B2 consist of Bradyrhizobium sp. USDA 3456+ Serratia marcescens MH6+ Psuedomonas fluorescensIFO 2034.

The layout of the experiment was a split-plot design in three replicates. The experimental plots were 45 unit including four sources of organic fertilizers, plus control $\times$ two different mixtures of biofertilizer, plus control $\times$ three replicates. The area of each plot was $21 \mathrm{~m}^{2}(7 \mathrm{~m}$ length $\times 3$ $\mathrm{m}$ width), including 5 rows. The main plots were representing the biofertilizer treatments, whereas peanut seeds were inoculated with gamma irradiated vermiculite based inoculums at a rate of $300 \mathrm{~g} / 50 \mathrm{~kg}$ seeds using 16\% Arabic gum solution as a sticking agent. The sub main plots were treated with one of the organic fertilizer (control, FYM, SPC, FYM+ECT and ECT).

Before planting in 2016 and 2017 growth seasons, SPC and FYM were added at rate of $5 \mathrm{Mg} / \mathrm{fed}$, where feddan area equal $4200 \mathrm{~m}^{2}$ (0.42 hectare),while, ECT was added at a rate of $75 \mathrm{~L} /$ fed in two equal doses, after 20 and 30 days of planting. The treatment of FMY+ECT was carried out at a rate of $2.5 \mathrm{Mg} \mathrm{FYM} \mathrm{/} \mathrm{fed}$ $+37.5 \mathrm{~L} \mathrm{ECT/} \mathrm{fed.} \mathrm{At} \mathrm{final} \mathrm{soil} \mathrm{preparation,} \mathrm{all}$ plots were fertilized byordinary super phosphate $\left(15.5 \% \mathrm{P}_{2} \mathrm{O}_{5}\right)$ at a rate of $200 \mathrm{~kg} / \mathrm{fed}+500 \mathrm{~kg} /$ fed of agricultural gypsum. Ammonium sulphate $\left(\mathrm{NH}_{4}\right)_{2} \mathrm{SO}_{4}(20.3 \% \mathrm{~N})$ was applied as source of $\mathrm{N}$ fertilizer at a rate of $25 \mathrm{~kg} \mathrm{~N} /$ fed corresponding to $123.15 \mathrm{~kg}\left(\mathrm{NH}_{4}\right)_{2} \mathrm{SO}_{4} / \mathrm{fed}$. It was added in two equal doses, i.e. after 20 and 30 days of planting. At the same time of mineral $\mathrm{N}$ fertilization, all plots received potassium fertilizer in the form of potassium sulphate $\left(48 \% \mathrm{~K}_{2} \mathrm{O}\right)$ at a rate of 100 $\mathrm{kg} /$ fed.

TABLE 2. Some chemical properties of the used three organic fertilizers

\begin{tabular}{|c|c|c|c|c|c|c|c|c|}
\hline \multirow{2}{*}{$\begin{array}{l}\text { Source of organic } \\
\text { fertilizers }\end{array}$} & \multirow{2}{*}{$\begin{array}{l}\text { Organic } \\
\text { C }\end{array}$} & \multirow{2}{*}{$\begin{array}{l}\text { Organic } \\
\text { matter }\end{array}$} & \multirow{2}{*}{$\begin{array}{c}\text { Total } \\
\mathbf{N}\end{array}$} & \multirow{2}{*}{$\begin{array}{l}\mathrm{C} / \mathrm{N} \\
\text { ratio }\end{array}$} & \multirow{2}{*}{ pH } & \multirow{2}{*}{ EC } & \multicolumn{2}{|c|}{ Total } \\
\hline & & & & & & & $\mathbf{P}$ & $\mathbf{K}$ \\
\hline $\begin{array}{l}\text { Farmyard manure } \\
\text { "FYM" }\end{array}$ & $22.05 \%$ & $38.01 \%$ & $1.20 \%$ & 18.37 & 8.38 & 3.80 & $0.70 \%$ & $1.90 \%$ \\
\hline $\begin{array}{l}\text { Solid plant compost } \\
\text { "SPC" }\end{array}$ & $18.00 \%$ & $31.03 \%$ & $1.42 \%$ & 12.68 & 7.79 & 3.53 & $0.46 \%$ & $1.60 \%$ \\
\hline $\begin{array}{l}\text { Enriched compost tea } \\
\text { "ECT" }\end{array}$ & $58.0 \mathrm{~g} / 1$ & $99.9 \mathrm{~g} / 1$ & $4.10 \mathrm{~g} / 1$ & 14.15 & $6.85^{*}$ & $3.89 *$ & $5.70 \mathrm{~g} / 1$ & $8.20 \mathrm{~g} / 1$ \\
\hline
\end{tabular}


Directly after inoculation, peanut (Giza $5 \mathrm{cv}$.) seeds, (kindly provided by Field Crop Research Institute, Agricultural Research Center, Giza, Egypt) were planted with seeding rate of $50 \mathrm{~kg}$ seeds / fed at $10^{\text {th }}$ and $15^{\text {th }}$ of May 2016 and 2017 in order. Each hole was planted by two seeds at 2 $\mathrm{cm}$ depth and distance of $20 \mathrm{~cm}$ between holes. After 15 day of planting, the plants of each hole were thinned to one plant. At maturity stage of pods (122 days from planting) in the two growth seasons, the plants of one length meter of each replicate were randomly harvested and separated into shoots and pods, air-dried, oven-dried at 70 $\mathrm{C}$ for $48 \mathrm{~h}$, to determine dry weight of straw and pods yield $\left(\mathrm{kg} \mathrm{fed}^{-1}\right)$. Seeds were separated from the pods and weighed separately and shelling (\%) $\{=$ (weight of seeds / weight of pods) $\times 100\}$ of peanut plants was calculated.

A $0.2 \mathrm{~g}$ of each dried fine plant materials, i.e. shoots and seeds were digested in $10 \mathrm{~mL}$ mixture of concentrated $\mathrm{H}_{2} \mathrm{SO}_{4}$ and $\mathrm{HClO}_{4}$ at a ratio of $3: 1$ at $250 \square$. The clear digest was diluted to $100 \mathrm{ml}$ with distilled water (Chapman and Pratt, 1961). The contents of $\mathrm{N}, \mathrm{P}$ and $\mathrm{K}(\%)$ in the diluted digest were determined following the methods described by Cottenie et al. (1982). Seed crude protein percentage was calculated by multiplying the concentration of $\mathrm{N}(\%)$ by 6.25 (AOAC,1990). Oil percentage in seeds was determined by using Soxhlet apparatus and petroleum ether as an organic solvent as described by AOAC (1990). Finally, the relative change $(\%)$ of the obtained data were calculated.

Where: The relative change "RC" (\%) = \{(Parameter value with treatment -Parameter value with control) / Parameter value with control $\} \times 100$.

\section{Statistical analyses}

Statistical analysis was done using Costat package program, version 6.4 (Cohort software, USA). The differences among the means of different treatments were tested using the least significant differences (LSD) at probability 5\% as described by Snedecor and Cochran (1980).

\section{Results and Discussion}

Straw and pod yields

Data in Table 3 showed the yield of peanut straw and pods $\left(\mathrm{kg}\right.$ fed $\left.^{-1}\right)$ as affected by application of different types of organic fertilizers and mixtures of bio-fertilizers. Presented data showed that sole application of organic fertilizers and in combination with different bio-fertilizers mixtures resulted in a significant increase in both straw and pods yields of peanut grown in sandy soil. It was clear that there were a wide variations in response of peanut to different used organic fertilizers where the maximum response was obtained with the treatment of ECT followed by FYM + ECT, while the lowest was recorded for FYM treatment. For example, the straw and pods yield as a result of organic fertilizers application alone was 2554, 2319; 2120, 2077; 1958, 1968 and $1796,1769 \mathrm{~kg} \mathrm{fed}^{-1}$ for the treatments of ECT, FYM+ECT, SPC and FYM, respectively. The effect of organic fertilizers may also be cleared from the positive values of RC (\%) of both straw and pod yield (Table 3). Hammad (2019) pointed out the importance of added organic fertilizers on plant (common been) growth and productivity. Baddour et al. (2017), Helmi (2018), AbouHussien et al. (2019) and Tantawy et al. (2019a) also showed that plant growth was increased due to organic fertilizers application.Bio fertilizers in the two mixtures (B1 and B2) showed a significant increase in peanut straw and pod yield compared to control. It was clear that with all the studied organic fertilizers, application of bio-fertilizers resulted in increase in both straw and pod yield of peanut. The obtained data also, show that there is superior effect of B2 application on the increase of straw and pod yields compared with that resulted from B1 application. On average of all different organic fertilizers, the straw yield of peanut as a result of B1 application was $2291 \mathrm{~kg} \mathrm{fed}^{-1}$ while it was $2388 \mathrm{~kg} \mathrm{fed}^{-1}$ with B2 application. This trend may be cleared from the higher RC (\%) values with B2 compared with that of B1. These increases resulted from the enhanced effect of bio fertilization on nodulation efficiency and nutrients uptake. In this respect, similar results were obtained by Abdel-Salam (2019), Marei (2019) and Tantawy et al. (2019b).

\section{Seed yield and shelling percentage}

Data of peanut seed yield and shelling percentage and their relative change as affected by application of different organic and bio fertilizer are presented in Table 4. These data show that seed yield and shelling percentage significantly responded to the application of different types of organic fertilizers and/ or bio fertilizer mixtures. Seeds yield response to application of organic fertilizers varied widely as cleared from RC (\%) values of different organic fertilizers application. For example, seeds yield increased from 318.4 $\mathrm{kg} \mathrm{fed}^{-1}$ in the control treatment to 963,1346 , 1560 and $1938 \mathrm{~kg} \mathrm{fed}^{-1}$ with the application of FYM, SPC, FYM+ECT and ECT treatments with corresponding RC values of 66.94,76.59, 79.59 and $83.57 \%$, respectively. It is clear that, the treatment of ECT resulted in the superior increase in seed yield followed by the treatment of FYM+ECT whereas as the lowest increase 
resulted from FYM application. Similar effect of organic fertilizers on the increase of crops productivity was found by Abou-Hussien et al. (2017) on barely, Helmi (2018) on sugar beet, Hammad (2019) on common beans and Tantawy et al. (2019a) on barely under different newly reclaimed soils of Egypt.

Application of bio fertilizer mixtures (B1 and B2) significantly increased seed yield peanut as compared with un-inoculated plants (B0). With the same treatments of organic fertilizers, seed yield of peanut plants treated with B2 was higher than that found with B1. The superior effect of B2 may also be cleared from the higher corresponding RC (\%) values. For example, the average yield of peanut seeds of different organic fertilizers increased from $1225 \mathrm{~kg} \mathrm{fed}^{-1}$ in the B0 treatment to 1410 and $1627 \mathrm{~kg} \mathrm{fed}^{-1}$ in the treatments of B1 and B2, respectively. In thisrespect similar results were obtained byEl-Noamany (2013), Ghaly et al. (2018) and Marie (2019).

Shelling percentage of peanut crop is considered an important parameter of its yield quality. Data in Table 4 showed the effect of the studied treatments on shelling percentage of peanut grown on sandy soil. All fertilization treatments resulted in clear significant increase in shelling percentage, where their relative change values were positive. Organic fertilization by different sources individually or in combination with bio fertilizer mixtures resulted in a significant increase in shelling percentage compared with the control treatment. The highest shelling percentage and its relative changes were found with the plants fertilized by ECT compared with other used organic manures. Increase in peanut yield and quality is due to improved soil physical and chemical properties and enhanced soil biological activities such as, soil enzymes and activity and increased microbial biomass as a result of organic fertilizers application (Lin et al., 2010 and Abd El-Halim et al., 2016). Abdel-Salam (2019) and Hammouda et al. (2019) found that application of bio- and organic fertilizers increased the seed weight percentage of total yield of peanut.

TABLE 3. Straw and pod yield of peanut $\mathrm{kg} \mathrm{fed}^{-1}$ and their relative changes as affected by bio- and organic fertilizers

\begin{tabular}{|c|c|c|c|c|c|}
\hline \multicolumn{2}{|c|}{ Treatments } & \multicolumn{2}{|c|}{ Straw yield } & \multicolumn{2}{|c|}{ Pods yield } \\
\hline Biofertilizer & Organic & $\mathrm{kg} \mathrm{fed}^{-1}$ & $\mathrm{RC}(\%)$ & kg fed-1 & $\mathrm{RC}(\%)$ \\
\hline \multirow{5}{*}{ B0 } & $\mathrm{O} 0$ & $1526.9 \mathrm{~m}$ & -- & $1000.3 \mathrm{~h}$ & -- \\
\hline & FYM & $1796.0 \mathrm{j}$ & 14.98 & $1769.1 \mathrm{efg}$ & 43.46 \\
\hline & $\mathrm{SPC}$ & $1958.8 \mathrm{i}$ & 22.05 & 1968.7cdefg & 49.19 \\
\hline & $\mathrm{FYM}+\mathrm{ECT}$ & $2120.8 \mathrm{~h}$ & 28.00 & 2077.1bcdef & 51.84 \\
\hline & ECT & $2554.2 \mathrm{e}$ & 40.22 & $2319.8 \mathrm{bcd}$ & 56.88 \\
\hline \multirow{5}{*}{ B1 } & $\mathrm{O} 0$ & 1643.01 & -- & $1520.0 \mathrm{~g}$ & -- \\
\hline & FYM & $1973.3 \mathrm{i}$ & 16.74 & 1906.5defg & 20.27 \\
\hline & $\mathrm{SPC}$ & $2338.4 \mathrm{~g}$ & 29.74 & 2025.0cdef & 24.94 \\
\hline & $\mathrm{FYM}+\mathrm{ECT}$ & $2597.3 \mathrm{~d}$ & 36.74 & $2183.4 \mathrm{bcdef}$ & 30.39 \\
\hline & ECT & $2906.1 b$ & 43.46 & $2503.8 \mathrm{ab}$ & 39.29 \\
\hline \multirow{5}{*}{ B2 } & $\mathrm{O} 0$ & $1688.9 \mathrm{k}$ & -- & $1731.8 \mathrm{fg}$ & -- \\
\hline & FYM & $2121.0 \mathrm{~h}$ & 20.37 & 2006.6cdef & 13.70 \\
\hline & $\mathrm{SPC}$ & $2434.7 f$ & 30.63 & 2213.1 bcde & 21.75 \\
\hline & $\mathrm{FYM}+\mathrm{ECT}$ & $2683.4 \mathrm{c}$ & 37.06 & $2393.0 \mathrm{bc}$ & 27.63 \\
\hline & ECT & $3016.5 a$ & 44.01 & $2923.4 \mathrm{a}$ & 40.76 \\
\hline \multirow{3}{*}{$\begin{array}{c}\text { Average } \\
\text { Biofertilizer }\end{array}$} & B0 & $1991.3 \mathrm{c}$ & -- & $1827.0 \mathrm{c}$ & -- \\
\hline & B1 & $2291.6 b$ & 15.08 & $2027.7 b$ & 10.99 \\
\hline & B2 & $2388.9 a$ & 19.97 & $2253.6 \mathrm{a}$ & 23.35 \\
\hline \multirow{5}{*}{ Average organic } & $\mathrm{O} 0$ & $1619.6 \mathrm{e}$ & -- & $1417.4 d$ & -- \\
\hline & FYM & $1963.4 d$ & 21.22 & $1894.1 \mathrm{c}$ & 33.63 \\
\hline & SPC & $2244.0 \mathrm{c}$ & 38.55 & $2069.0 \mathrm{bc}$ & 45.97 \\
\hline & $\mathrm{FYM}+\mathrm{ECT}$ & $2467.1 b$ & 52.32 & $2217.9 b$ & 56.48 \\
\hline & ECT & $2825.6 a$ & 74.45 & $2582.3 \mathrm{a}$ & 82.19 \\
\hline
\end{tabular}


TABLE 4. Seed yield $\mathrm{kg} \mathrm{fed}^{-1}$ and shelling percentage of peanut and their relative changes as affected by bio- and organic fertilizers

\begin{tabular}{cccccc}
\hline \multicolumn{2}{c}{ Treatments } & \multicolumn{2}{c}{ Seed yield } & \multicolumn{2}{c}{ Shelling percentage } \\
\hline Biofertilizer & Organic & kg fed ${ }^{-1}$ & RC $(\%)$ & $\%$ & RC (\%) \\
\hline \multirow{2}{*}{ B0 } & O0 & 318.401 & -- & $33.05 \mathrm{~g}$ & -- \\
& FYM & $963.04 \mathrm{ij}$ & 66.94 & $56.14 \mathrm{def}$ & 41.13 \\
& SPC & $1346.72 \mathrm{fg}$ & 76.36 & $68.94 \mathrm{abcde}$ & 52.06 \\
& FYM+ ECT & $1560.32 \mathrm{de}$ & 79.59 & $78.18 \mathrm{ab}$ & 57.73 \\
& ECT & $1938.08 \mathrm{bc}$ & 83.57 & $84.73 \mathrm{a}$ & 60.99 \\
B1 & O0 & $725.44 \mathrm{k}$ & -- & $47.70 \mathrm{fg}$ & -- \\
& FYM & $1138.56 \mathrm{hi}$ & 36.28 & $59.91 \mathrm{cdef}$ & 20.38 \\
& SPC & $1419.84 \mathrm{ef}$ & 48.91 & $71.60 \mathrm{abcd}$ & 33.38 \\
& FYM+ ECT & $1666.80 \mathrm{~d}$ & 56.48 & $78.46 \mathrm{ab}$ & 39.20 \\
B2 & ECT & $2103.44 \mathrm{~b}$ & 65.51 & $84.92 \mathrm{a}$ & 43.83 \\
& O0 & $902.24 \mathrm{j}$ & -- & $51.99 \mathrm{ef}$ & -- \\
& FYM & $1241.84 \mathrm{gh}$ & 27.35 & $63.17 \mathrm{bcdef}$ & 17.70 \\
& SPC & $1597.60 \mathrm{~d}$ & 43.53 & $74.28 \mathrm{abc}$ & 30.01 \\
Average & FYM+ ECT & $1907.60 \mathrm{c}$ & 52.70 & $79.68 \mathrm{ab}$ & 34.75 \\
& ECT & $2487.92 \mathrm{a}$ & 63.74 & $85.34 \mathrm{a}$ & 39.08 \\
& B0 & $1225.31 \mathrm{c}$ & -- & $64.21 \mathrm{~b}$ & -- \\
& B1 & $1410.82 \mathrm{~b}$ & 15.14 & $68.52 \mathrm{a}$ & 6.71 \\
& B2 & $1627.44 \mathrm{a}$ & 32.82 & $70.89 \mathrm{a}$ & 10.40 \\
& O0 & $648.69 \mathrm{e}$ & -- & $44.25 \mathrm{~d}$ & -- \\
& FYM & $1114.48 \mathrm{~d}$ & 71.80 & $59.74 \mathrm{c}$ & 35.01 \\
& SPC & $1454.72 \mathrm{c}$ & 124.26 & $71.61 \mathrm{~b}$ & 61.83 \\
& FYM+ ECT & $1711.57 \mathrm{~b}$ & 163.85 & $78.77 \mathrm{ab}$ & 78.01 \\
& ECT & $2176.48 \mathrm{a}$ & 235.52 & $85.00 \mathrm{a}$ & 92.09 \\
\hline
\end{tabular}

Inoculation of peanut plants by B1 and B2 individually and in combination with organic fertilizers resulted in significant increases in shelling percentage. With the same treatment of organic fertilization, shelling percentage of peanut plants fertilized by B2 was higher than the treatment associated with the treatment of B1. This trend is in harmony with the effect of these fertilizers on plant growth and seeds yield. The enhanced effect of bio fertilization on the seeds yield of peanut plants was pointed by Abdel-Wahab et al. (2006) and Abdel-Salam (2019). These resulted may be cleared from RCB $(\%)$, where RCB of shelling percentage in the plants fertilized by B2 were higher than those found in the plants fertilized by B1 with their individual application as well as in their combined applications with organic fertilizers. Increase in peanut yield and its components as a result of biofertilizer application may be attributed to increase in $\mathrm{N}$ availability via biological fixation. Nitrogen plays important roles in plant such as increasing photosynthesis rate, vegetative growth and subsequently yield and quality of peanut plants
Moreover, $\mathrm{N}$-fixation reduces the soil $\mathrm{pH}$ and thus indirectly increase availability of macro- and micro-nutrients. Awadalla and Abbas (2017) and El-Akhdaret al. (2018) obtained similar results.

Nutrient content

Data in Tables 5 and 6 showed N, P and K concentration (\%) and uptake $\mathrm{kg}$ fed $^{-1}$ of peanut plants. There was significant response in both nutrient concentration and uptake of straw and seeds of peanut plant to the studied treatments. Application of different types organic fertilizers significantly, increased nutrient concentration and uptake compared the control treatment however, their effect varied widely from type to another. The maximum increase in nutrient content uptake and resulted from the treatment of ECT while the lowest was resulted from the FYM treatment. For example, adding ECT increased the nitrogen uptake from 14.96 and $11.75 \mathrm{~kg}$ $\mathrm{fed}^{-1}$ in the control treatment to 32.18 and 89.93 $\mathrm{kg} \mathrm{fed}^{-1}$ by peanut straw and seeds respectively, in the un-inoculated plants. Peanut content of $\mathrm{P}$ and $\mathrm{K}$ followed similar trends. According to 
straw and seeds content of $\mathrm{N}, \mathrm{P}$ and $\mathrm{K}$ the added organic fertilizers write followed the descending order of ECT $>$ FYM+ECT $>$ SPC $>$ FYM. Organic fertilizers application to soil improved soil physical and chemical properties, increased availability of essential macro- and micronutrients and hence increased nutrients uptake by peanut. These results are in the harmony with the effect of these organic fertilizers on soil fertility (Mahmoud, 2017 and Bekele et al., 2019) as well as their effect on plant growth (Emam, 2018 and Abou- Hussien et al., 2019).

In addition, biofertilization with the, respectively two different sources i.e., " $\mathrm{B}_{1}$ " i.e. A.braselinse + B.megatherium + A.chroococcum and " $\mathrm{B}_{2}$ " i.e. consist of Bradyrhizobium. $s p+$ S.marcescens + P.fluorescens resulted in significant increases in nutrient in both shoots and seeds concentrations (\%) and their corresponding uptake values $\left(\mathrm{kg} \mathrm{fed}{ }^{-1}\right)$, as cleared from corresponding positive RC (\%) values. In both straw and seeds of peanut plants nutrient content (\%) and uptake $\left(\mathrm{kg} \mathrm{fed}^{-1}\right)$ in the plants fertilized by $\mathrm{B}_{2}$ were higher than the corresponding fertilized with the treatment $B_{1}$. Effect of added bio-fertilizer mixtures on nutrients uptake from $\mathrm{RC}$ of nutrient uptake by shoots and seeds as a result of $\mathrm{B}_{1}$ and $\mathrm{B}_{2}$ applications. For example, the average content of $\mathrm{N}, \mathrm{P}$ and $\mathrm{K}$ of increased from $1.12,0.22$ and $0.65 \%$ in the control treatment to $1.25,0.31$ and $0.46 \%$ with $\mathrm{B} 1$ application and to $1.33,0.34$ and $0.787 \%$ with B2 application. Increase in nutrient concentration as a result of bio-fertilizer application may be due to the role of bi-fertilizers in increasing available nitrogen and production of plant growth stimulants which improve cell division, root length, root biomass, plant growth and consequently nutrient absorption ( Ravikumaret al. 2004; Zaki et al., 2017 and ElNaqme et al., 2019). Similar significant effects of bio-fertilizers application on nutrient content of different plants was reported by Singh et al. (2009); Abdel-Salam (2019) and Marie (2019).

\section{Oil and protein content}

Crude protein content $(\%)$ in the seeds of peanut plants presented in Fig. 1 in relation with different fertilization treatments of bio and organic fertilizers seemed to follow an almost similar pattern to that mentioned with the seeds content of N. For example, crude protein content $(\%)$ in the seeds of peanut plants received the treatment of ECT increased from $23.06 \%$ in the control treatment to $29.00 \%$ in the uninoculated plants. Crude protein content was maximum in the treatment of ECT in both inoculated and uninoculated plants. Similar trend was observed with the oil content of peanut seeds. El-Kramany et al. (2007), Mahrous et al. (2015) and Hammad (2019) obtained similar results.

Data in Fig. 2 show peanut seeds content (\%) of oil as affected by individual and combined applications of bio and organic fertilizers under sandy soil conditions. These data show significant increases duo to these fertilization treatments on oil content of seeds of peanut under study. Therefore, all RC values of oil content in relation with the studied treatments were positive. Individual applications of organic fertilizers increased the seeds content of oil from $40.76 \%$ in the control treatment to $41.38,41.96,42.11$ and $42.40 \%$ with RCO values of $1.50,2.94,3.21$ and $3.87 \%$ with the treatments of FYM, SPC, FYM+ECT and ECT respectively. The increases in the seeds content of oil resulted from the added fertilizers effect on enzymes activities and other biochemical reaction within different plant tissues (Badole et al. 2001 and 2004; Mahrous, 2015). Also, biofertilization by $\mathrm{B}_{1}$ i.e. A.braselinse $+B$. megatherium + A.chroococcum and $\mathrm{B}_{2}$ i.e. Bradyrhizobium. sp + S.marcescens + P.fluorescens increased the seeds content of oil from $41.72 \%$ in the control treatment to 45.38 and $46.99 \%$, respectively. Application of bio- and organic fertilizers resulted in improved soil chemical, physical and biological properties as well as enhanced plant growth and nutrients uptake which finally reflected positively on peanut content of oil and protein. These results indicated that combined application of bio- and organic fertilizers increased both yield and quality of peanut plants grown on sandy soils. These results are in harmony with those obtained by Awadalla, and Abbas (2017) and Zaki et al. (2017).

\section{Conclusion}

In conclusion, the obtained results emphasized that organic fertilizers application increased sandy soil productivity of peanut as well as quality of produced yield. Incorporation of bio-fertilizers along with bio-fertilizers resulted in superior increase in peanut yield and quality parameters. These results emphasized the hypotheses of this study that integrated fertilization approach can be used as an alternative approach for increasing productivity while sustaining environment and maintaining soil health. 


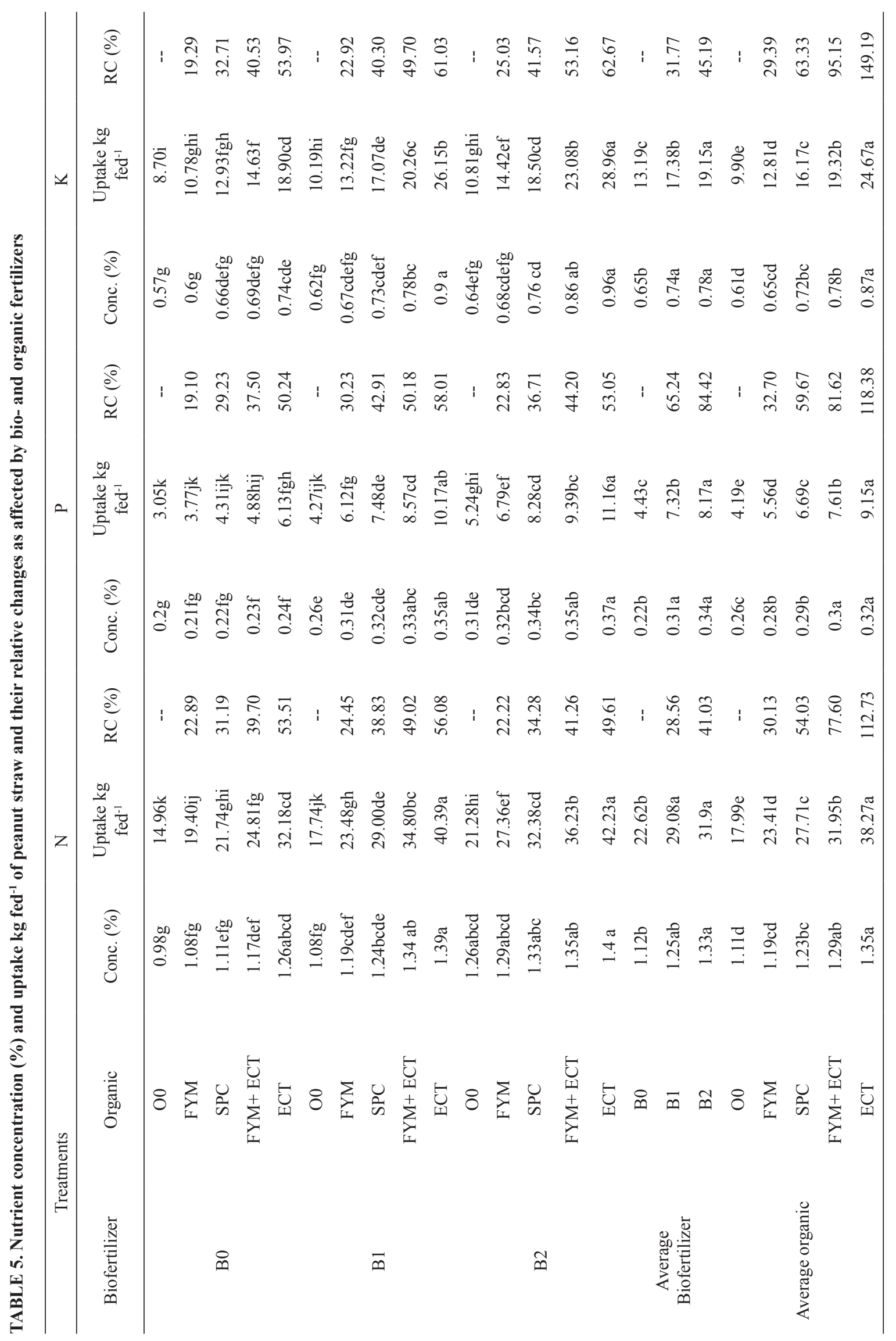

Env. Biodiv. Soil Security Vol. 4 (2020) 


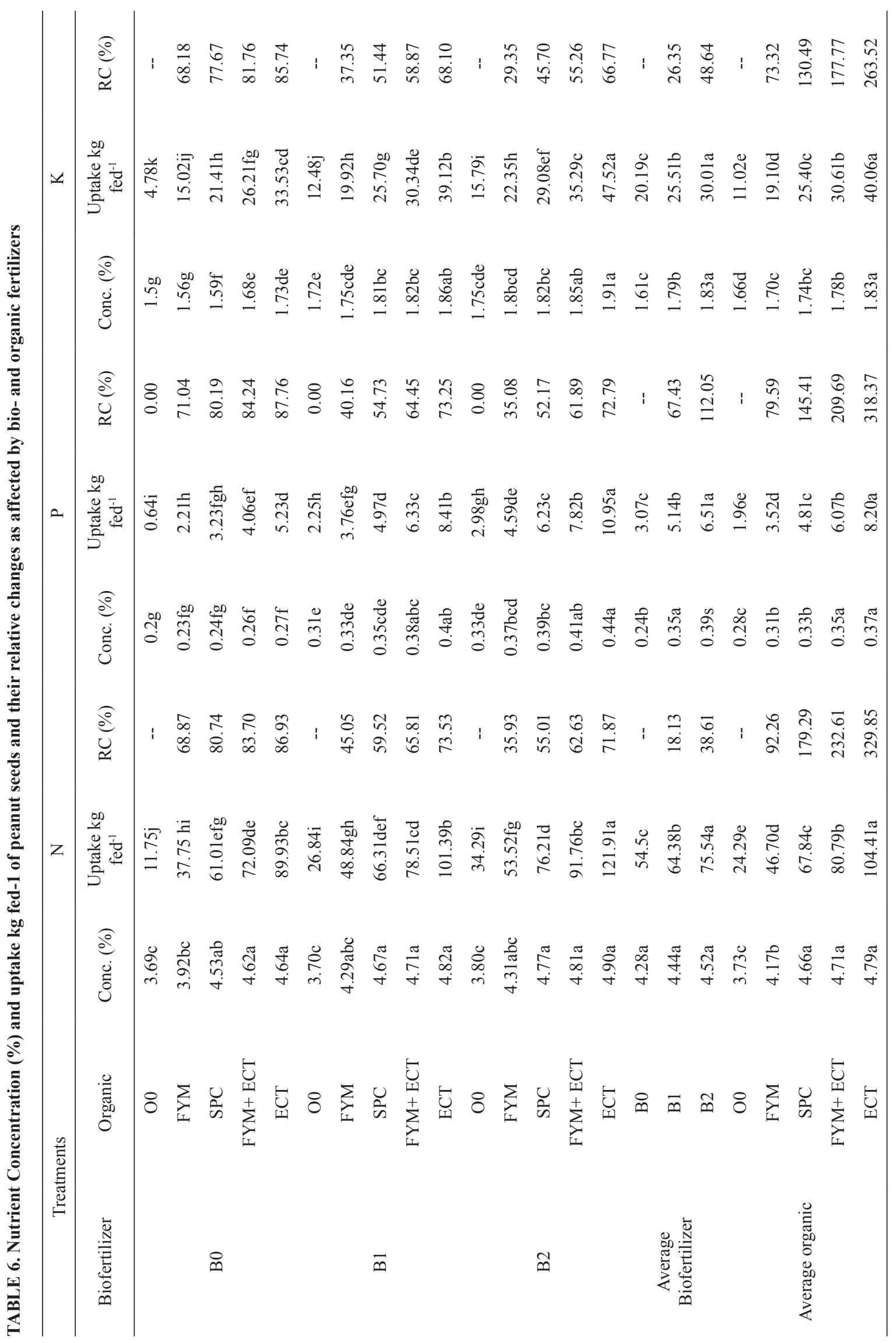




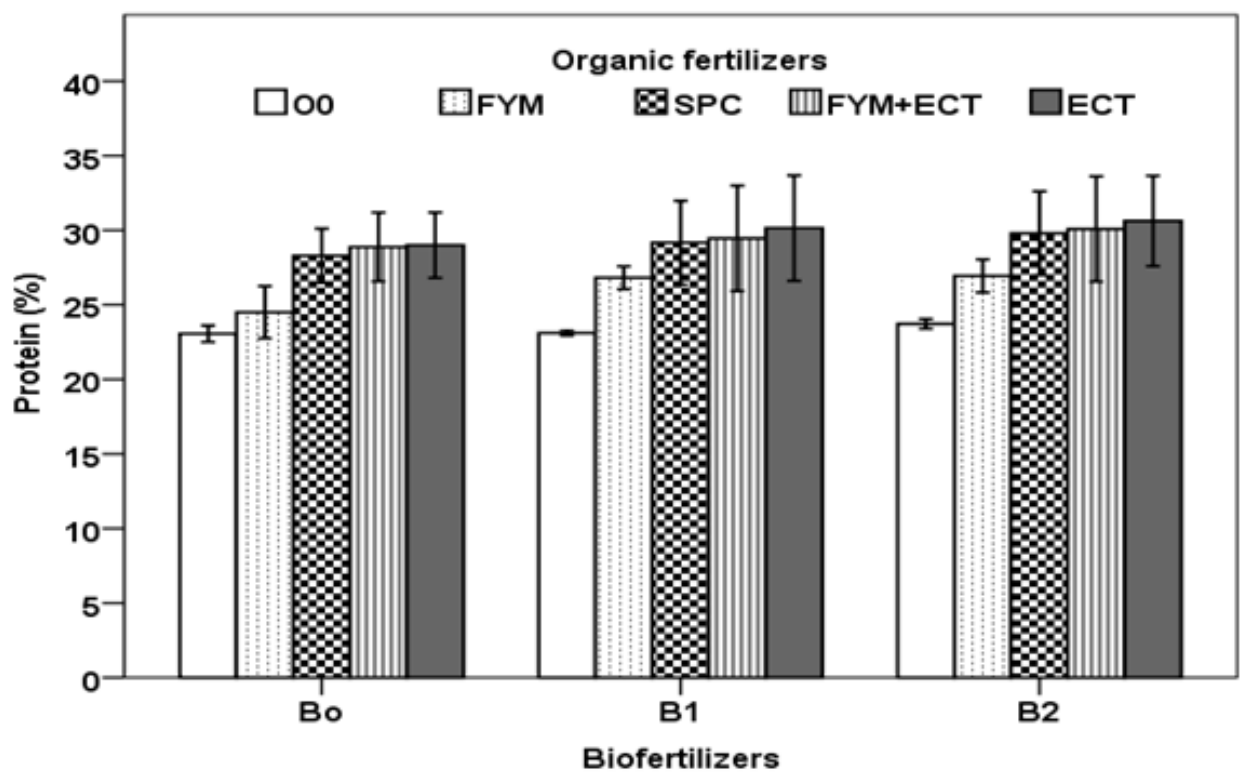

Fig.1. Crude protein content (\%) of peanut seeds as affected by bio- and organic fertilizers

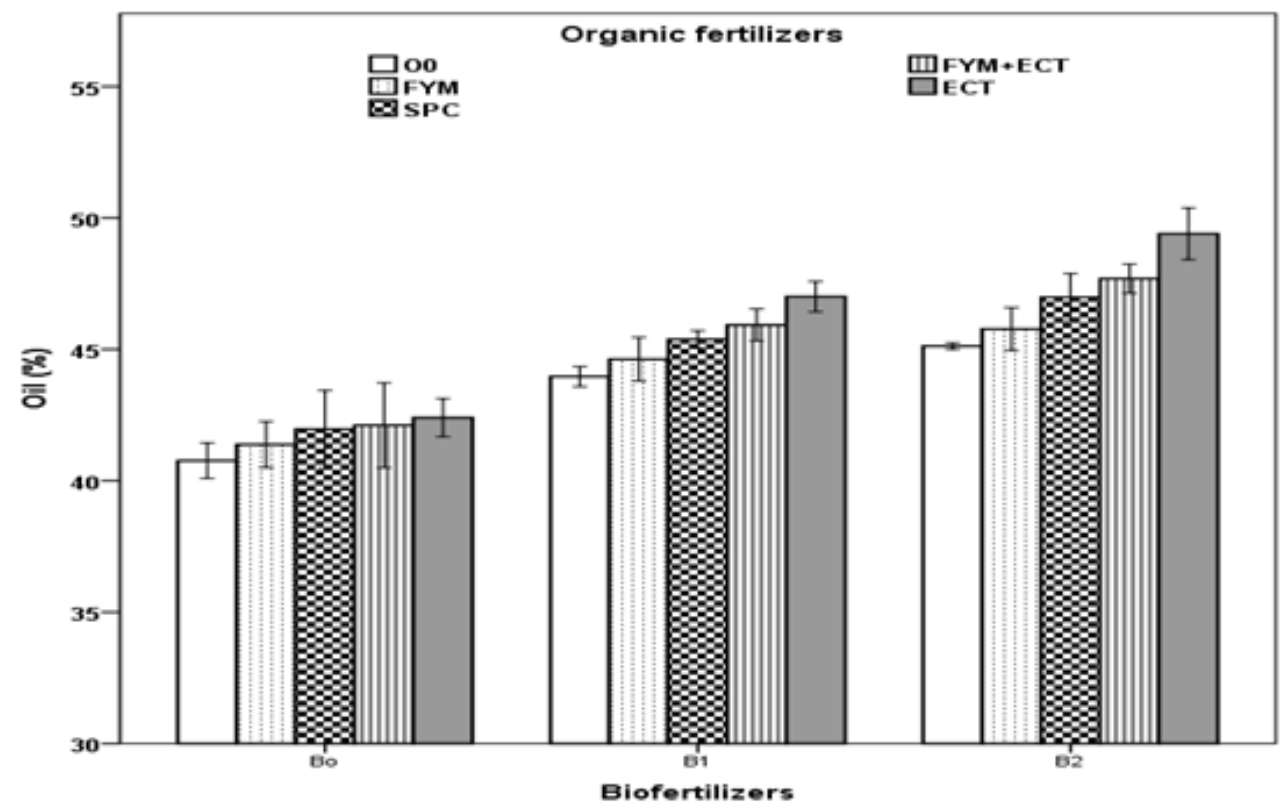

Fig. 2. Oil content (\%) of peanut seeds as affected by bio- and organic fertilizers 


\section{$\underline{\text { References }}$}

A.O.A.C. (1990) Association of Official Methods of Analysis Chemists, Official Methods of Analysis". $5^{\text {th }}$ Ed. Washington, D. C. , USA.

Abd El-Halim, A. K., Awad,A. M.and Moursy, M. E.(2016) Response of peanut to some kinds of organic fertilizers under drip and Sprinkler irrigation systems. Alex. Sci. Exch. J., 37: 703-713.

Abdel-Salam, S.S.A. (2019) Studies on peanut Bradyrhizobiumbroth inocula as affected by irrigation water quality in newly reclaimed desert soils. M. Sc. Thesis, Fac. of Agric., Menoufia Univ., Egypt.

Abdel-Wahab, A. F. M., Badawi,F. Sh. F.,Mekhemar, G. A. A. and El-Farghal, W. M. (2007) Effect of enriched compost tea and Rhizobacteria on Nodulation, growth and yield of chick pea in sandy soil. Menoufia J. Agric. Res., 32, 297-321.

Abdel-Wahab, A. F., Mekhmer, G. A. A.,Shehata, H. and Hanafi, A. A. (2006) Effect of plant growth bioprotecting and promoting rhizobacteria and compost on the health and productivity of peanut crop in sandy soil. Menoufia J. Agric. Res., 31, 1323-1348.

Abou- Hussien, E. A., Elbaalawy, A. M. and Hamad, M. M. (2019) Chemical properties of compost in relation to calcareous soil properties and its productivity of wheat. Egypt. J. Soil Sci., 59, 85-97.

Abou-Hussien, E. A., Nada, W. M. andElgezery, M. Kh. (2017) Evaluation efficiency of sulphur fertilizer in calcareous soil amended by compost. Menoufia J. of Soil Sci.,2, $59-72$.

Ansari, R. A.and Mahmood, I.(2017) Optimization of organic and bio-organic fertilizers on soil properties and growth of pigeon pea,ScientiaHorticulturae,226: 1-9.

Awadalla, A. O. and Abbas, M. T. (2017) Peanut (Arachishypogaea L.) yield and its components as affected by $\mathrm{N}$-fertilization and diazotroph inoculation in Toshka desert soil-South ValleyEgypt. Environ Risk Assess Remediat.,1:49-55.

Baddour, A. G., Rashwan,E. and El-Sharkawy,T. (2017)Effect of organic manure, antioxidant and proline on corn (Zea mays L.) grown under saline conditions. Env. Biodiv. Soil Security,1:203-217.

Badole, S. B., More,S. D.,Adsul, P. B. and Raut, M. M. (2001) Residual effect of different organic and inorganic nutrient sources on yield and quality of groundnut. Annals of Plant physiology, 15, 54-57.

Badole, S. B., More,S. D.,Adsul,P. B., Shaikh, A. K. and Dhamak, A. L. (2004) Residual effect of organic manures and inorganic fertilizers on yield and gross monetary returns of groundnut (ArachishypogaeaL.). J. of Soils and Crops, 14,196-197.

Bekele, G., Dechassa,N.,Tana, T. and Sharma, J. J. (2019) Effects of nitrogen, phosphorus and vermicompost fertilizers on productivity of groundnut (Arachis hypogaea L.) in Babile, East. Ethiopia Agron. 17:1532-1546.

Chapman, H. D. and Pratt, P. F. (1961) Methods of Analysis for Soils, Plants and Waters. Division of Agric. Sci., Univ. California, Riverside. USA.

Cottenie, A., Verloo,M.,Kiekens,L.,Velgh, G. and Camerlynck, R. (1982) Chemical Analysis of Plants and Soils. State Univ. Ghent Belgium.

El- Howeity, M. A., Abdel-Gwad, Sh. A. and Elbaalawy, A. M. (2019) Effect of bio-organic amendments on growth, yield, nodulation status, an microbial activity in the rhizosphere soil of peanut plants under sandy soil conditions. J. Soil Sci. and Agric. Eng., Mansoura Univ., 10, 299 - 305.

El-Akhdar, I., Omara,A. and Abdel-Rahman, M. (2018) Intergradation of different fertilizers for sustainable agriculture enhanced growth and yield of wheat (Triticum aestivum L.).Env. Biodiv. Soil Security, 2, 11-23.

El-Behlak, S. M. E. (2016) Use of Organic and Mineral Fertilization for Improving Peanut Production in Sandy Soil. M. Sc. Thesis, Fac. of Agric., Cairo Univ., Egypt.

El-Kramany, M. F., Bahr, A. A., Mohamed, F. M. and Kabesh, M. O. (2007) Utilization of bio-fertilizers in field crops production. 16-groundnut yield, its components and seeds content as affected by partial replacement of chemical fertilizers by bioorganic fertilizers. J. Applied Sciences Research, 3, 25-29.

El-Naqme, K., El-Dissoky, R., Aiad, M. (2019)Impact of green manure, mineral and bio fertilizers on soil fertility, onion-maize productivity and N-use efficiency.Env. Biodiv. Soil Security, 3, 11-28.

El-Noamany, N. E. A. (2013) Studies on diazotrophy in soils under different conditions. M. Sc. Thesis, Fac. of Agric., Menoufia Univ., Egypt.

Emam, A. A. E. (2018) Effect of some organic and inorganic fertilizers on plant irrigated by saline 
water. Ph. D. Thesis, Fac. of Agric., Menoufia Univ., Egypt.

Fageria, N.K., Ballgar, V. C. andJohanes, C.A. (1997) Growth and Mineral Nutrient of Field Crop, second ed. Marcel Dekker. Inc., New York, USA, p. 494.

Faiyad, R. M. N. (2014)Bioremediation of chemically polluted soils and its effect on plant growth. $P h . D$. Thesis, Fac. of Agric., Menoufia Univ., Egypt.

Gao, C., El-Sawah,A. M.,Ali,D. F. I.,Hamoud, Y. A.,Shaghaleh, H. and Sheteiwy, M. S. (2020) The Integration of Bio and Organic Fertilizers Improve Plant Growth, Grain Yield, Quality and Metabolism of Hybrid Maize (Zea mays L.). Agronomy. 10, 319 , https://doi.org/10.3390/agronomy10030319.

Ghaly, F. M. A., Soliman,M. A.,Moursy,A. A.,Ismail, M. M. and Elshayeb, M. M. A. (2018) Effect of organic and mineral nitrogen sources with and without Rhizobium inoculation on growth and yield of common bean plant using ${ }^{15} \mathrm{~N}$ tracer technique. $J$. Soil Sci. and Agric. Eng., Mansoura Univ. 9, 433 $-437$.

Ghabour, Th. K., Amal M. A. and Rahim, I. S. (2018) Land evaluation of old and recent cultivated reclaimed desert sandy soils in Egypt. Bioscience Res., 15,1787-1795.

Hammad, M. A. B. (2019) Combined effect of organic and mineral fertilization on nodulation and yield of common beans (Phaseolus vulgaris L.) under sandy soil conditions. M. Sc. Thesis, Fac. of Agric., Menoufia University, Egypt.

Hammouda, I. A., Elbaalawy, A. M. and El-Feishy, M. A. (2019)Effect of compost additives and application time of phosphorus in different methods on growth, productivity and quality of peanutin sandy soils. Egypt. J. Soil. Sci. 59, 339 - 352 .

Helmi, M.Y. (2018) Impact of using some chemical and biological treatments on ameliorating slat affected soil. Ph.D. Thesis, Fac. of Agric., Moshtohor, Benha Univ., Egypt.

Klute, A. (1986) Method of Soil Analysis. Part 1, Physical and Mineralogical Methods, $2^{\text {nd }}$ ed., Amer. Soc. of Agron., Madison, Wisconsin, USA.

Lin, X. J., Wang, F.,Cai, H.S.,Lin, R. B., He,C. M., Li, Q. H. and Li, Y. (2010) Effects of different organic fertilizers on soil microbial biomass and peanut yield. 2010. 19th World Congress of Soil Science, Soil Solutions for a Changing World, 73: 1 - 6 August 2010, Brisbane, Australia. Published on DVD.

Env. Biodiv. Soil Security Vol. 4 (2020)
Mahmoud, H. A. (2017) Organic amendments and their effect on status of some nutrients in soil and plant. Ph. D. Thesis, Fac. of Agric., Menoufia Univ., Egypt.

Mahrous, N. M., Sayed,A. S.,Hatem, H. A. and Sayed, M. E. E. (2015) Integrated use of organic, inorganic and bio fertilizers on yield and quality of two peanut (Arachis hypogaea L.) Cultivars grown in a sandy saline soil. American-Eurasian, J. Agric. \& Environ. Sci., 15, 1067-1074.

Marei, S. A. S. (2019) Impact of bio-fertilizer, magnetized water and salinity on common beans (Phaseolus vulgaris L.) plant. M. Sc. Thesis, Fac. of Agric., Menoufia Univ., Egypt.

Mengel, K., Kirkby,E. A., Kosegarten, H. and Appel, T. (2001) Principles of Plant Nutrition. Kluwer Acad. Publ, Dordrecht. The Netherlands.

Page, A. I., Miller, R. A. and Keene, D. R. (1982) Methods of Soil Analysis». Part 2: Chemical and Microbiological Properties. $2^{\text {nd }}$ Ed., Amer. Soc. of Agron., Madison, Wisconsin, USA.

Ravikumar, S., Kathiresan,K.,Thadedus, S., Maria I., BabuSelvam, M. and Shanthy, S. (2004) Nitrogenfixing Azotobacter from mangrove habitat and their utility as marine biofertilizers, J. Exper. Marine Bio. Eco. 312:5-17.

Shah, H., Khan, M. A.,Azeem,T., Majid, A. and Mehmood,A. (2012) The Impact of gypsum application on groundnut yield in rainfedPothwar: An Economic Perspective, Lahore J. Econ. 17, $83-$ 100.

Singh, R. P., Gupta, S. C. and Yadav, A. S. (2009) Effect of levels and sources of phosphorus andPSB on growth and yield of black gram. Leg. Res.,31, 139-141.

Snedecor, G. W. and Cochran, W. G. (1980) Statistical Methods. $7^{\text {th }}$ ed. The Iowa State University Press, Ames, Iowa.

Subrahmaniyan, K., Kalaiselven, P., Maniekam, G. and Arulmozhi, N. (2000) Response of confectionery groundnutcultivar to organic and inorganic fertilizers. Crop Res. Hisar., 19: 207-209.

Tantawy, M. F., Ahmed,M. A., El-Koumey, B. Y.,AbouHussien, E. A. and Emam, A.E. (2019a) Effect of farmyard manure on barley plants response to foliar applications of micronutrients and silicon in sandy soil irrigated by saline water. Menoufia J. Soil Sci.,4, 1-14. 
Tantawy, M. F., Fiyad,M. N., El-Shafei, F. S. and Marei, S. A. S. (2019b) Combined effect of saline and magnetized water and biofertilizer on nodulation and growth of common bean plants grown in clay and sandy soils. Menoufia J. Soil Sci., 4, 293-306.

Wua, S. C., Caob,Z. H., Lib,Z. G.,Cheunga, K.C. and Wonga, M. H. (2004). Effects of biofertilizer containing $\mathrm{N}$-fixer, $\mathrm{P}$ and $\mathrm{K}$ solubilizers and AM fungi on maize growth: a greenhouse trial. Geoderma, 125,155-166.

Zaki, N. M., Ahmed,A. G.,Hassanein, M. S. and Mohamed, M. H. (2017)Effect of organic and biofertilizer on yield and some chemical composition of two peanut cultivars under newly reclaimed sandy soil condition. Middle East J. App. Sci.7, 937-943. 